\title{
Proposal for the development of an international minimal data collection for juvenile dermatomyositis (JDM)
}

\author{
Liza J McCann, Clarissa Pilkington, Laura Beard, Angelo Ravelli, Adam Huber, Lucy R Wedderburn \\ From 18th Pediatric Rheumatology European Society (PReS) Congress \\ Bruges, Belgium. 14-18 September 2011
}

\section{Background}

There are a variety of groups collecting prospective data on patients with juvenile idiopathic inflammatory myopathies (IIM), including the UK JDM Cohort Biomarker Study and Repository ${ }^{1}$, CARRA, and Euromyositis. Datasets are partially overlapping. The development of a consensus minimal data collection would facilitate comparison and communication between these groups.

\section{Aim}

Proposal of a new international minimal data collection, potentially valuable in trials and clinical contexts, to be collected by clinicians for all JDM patients, respecting data protection and ownership.

\section{Methods}

A comparison was made of current variables collected within the UK JDM Cohort / Biomarker Study, CARRA, Euromyositis and those used in a multi-national inception study of 27 centres in Europe / Latin America. ${ }^{2}$ Variables common to at least 2 datasets were considered for inclusion, based on agreement between collaborators.

\section{Results}

The authors propose a minimum data collection for JDM patients, achievable by clinicians within their current practice. A more detailed collection of activity / damage indices could be performed in specialist / research environments.

\section{Conclusion}

Development of an international minimal data collection for use in trials would allow greater understanding of disease course and prognosis, enhance international collaboration between groups, and facilitate linking to biobanks. The proposed dataset would require testing through existing collaborations (IMACS, PRINTO and others). Collaboration with adult groups (eg. via Euromyositis) may allow harmonised data collection from paediatric to adult services, providing valuable outcome data for this rare disease.

Published: 14 September 2011

\section{References}

1. Martin N, Krol P, Smith S, et al: A national registry for juvenile dermatomyositis and other paediatric idiopathic inflammatory myopathies: 10 years' experience; the Juvenile Dermatomyositis National (UK and Ireland) Cohort Biomarker Study and Repository for Idiopathic Inflammatory Myopathies. Rheumatology (Oxford) 2011, 50(1):137-45.

2. Ravelli A, Trail L, Ferrari C, et al: Long-term outcome and prognostic factors of juvenile dermatomyositis: a multinational, multicenter study of 490 patients. Arthritis Care Res (Hoboken) 2010, 62(1):63-72.

doi:10.1186/1546-0096-9-S1-P51

Cite this article as: McCann et al:: Proposal for the development of an international minimal data collection for juvenile dermatomyositis (JDM). Pediatric Rheumatology 2011 9(Suppl 1):P51.

Submit your next manuscript to BioMed Central and take full advantage of:

- Convenient online submission

- Thorough peer review

- No space constraints or color figure charges

- Immediate publication on acceptance

- Inclusion in PubMed, CAS, Scopus and Google Scholar

- Research which is freely available for redistribution 